Lise Vikan Sandvik

Norges teknisk-naturvitenskapelige universitet (NTNU)

Anne Berit Emstad

Norges teknisk-naturvitenskapelige universitet (NTNU)

Simon Skov Fougt

Aarhus Universitet

DOI: http://dx.doi.org/10.5617/adno.7923

\title{
Forberedelse til lærerprofesjonen \\ - partnerskap og relevans i lærerutdanningen
}

Målet med dette temanummeret i Acta Didactica er å presentere ny skandinavisk forskning knyttet til utfordringer som lærerutdanningen står i når det gjelder områdene praksisrelevans og forskningsforankring, samt koblingen mellom de to. Disse to områdene løftes fram som sentrale utviklingsområder for lærerutdanningen i både nordisk og internasjonal forskning. De nordiske landene har kommet ulikt i gang med dette arbeidet. I Norge kommer utfordringene til uttrykk i den nasjonale strategien «Lærerutdanning 2025» (Kunnskapsdepartementet, 2017). I Sverige arbeides med en nasjonal forsøksordning (ULF 2017-2021) som handler om det samme. ${ }^{1}$ I Danmark har man også fått nasjonale krav om å koble sammen praksisrelevans og forskningsforankring, som er uttrykt i de ti ambisjonene for lærerutdanningen og som de Danske Professionshøjskoler arbeider ut fra. ${ }^{2}$ Mens Norge, Sverige og Danmark de siste årene opplever et stort trykk inn mot områdene praksisrelevans og forskningsforankring, har Finland siden 1970tallet hatt en tydelig forskningsbasert lærerutdanning, der fokuset har vært å utvikle en sterk forskningskompetanse hos lærerstudentene. Den finske lærerutdanningen har også konsentrert praksis i to bolker, en på bachelornivå og en på masternivå. Alle studentene har praksis i en universitetsskole, der alle veiledes av kvalifiserte veiledere (Alfdal, 2012).

Et annet viktig anliggende i lærerutdanningen er det faglige fokuset. Lærerutdanningen skal sørge for både faglig disiplinkompetanse og profesjonskompetanse. En viktig utfordring for all lærerutdanning er å sørge for en god balanse mellom disse to kompetanseområdene (Korthagen, 2004, 2010; Lid, 2013). Lærerutdanning har tradisjonelt vært betraktet som et utdanningsfelt med mange utfordringer knyttet til fragmentering av utdanningens ulike komponenter, og praksisrelevans har vært en stadig tilbakevendende utfordring for de fleste lærerutdanningene.

\footnotetext{
1 https://www.ulfavtal.se/

2 https://xn--danskeprofessionshjskoler-xtc.dk/3d-flip-book/10-ambitioner-for-en-bedre-laereruddannelse/
} 
For å utvikle en forskningsbasert lærerutdanning og lærerprofesjonalitet er det ikke tilstrekkelig at undervisningen på universitetet er forskningsbasert og satser på utvikling av studentenes FoU-kompetanse. Skolen som lceringsarena er helt sentral når det gjelder utvikling av lærerprofesjonalitet; det er der lærerstudentene får veiledet praksis, og det er der modeller for undervisning av elever blir erfart i praksis. Det er nettopp i skillet mellom universitet og skole at utfordringene knyttet til fragmentering oppstår (Hargreaves \& Fullan, 2012; Timperley et al., 2007).

Temanummeret presenterer bidrag som belyser ulike former for partnerskapsmodeller i lærerutdanningene både i Norge og i andre nordiske land. Temanummeret kan bidra til å kaste nytt lys over og gi inspirasjon til samarbeid mellom skole og universitet i lærerutdanningene og til å utvikle kunnskap om partnerskapsmodellenes betydning for integrering av de campusbaserte og de skolebaserte delene i lærerutdanningene. Vi presenterer også bidrag som belyser tematikken omkring utdanningenes relevans, med særlig fokus på utfordringer knyttet til praksisrelevans i skjæringspunktet mellom skole og lærerutdanning. I tillegg presenteres bidrag knyttet til relevansutfordringer ved etableringen av de femårige lærerutdanningene i Norge.

Vi har delt temanummeret i to. Første del vedrører partnerskap i lærerutdanningen, mens annen del behandler relevans i lærerutdanningen.

\section{Partnerskap i lærerutdanningen}

Det finnes flere forsøk på å møte utfordringene knyttet til fragmentering og relevans. Mens England og USA har møtt kritikken av lærerutdanningen om å være for fragmentert og for praksisfjern ved å redusere universitetenes (høyskolenes) komponenter i utdanningen og ved å flytte større deler av utdanningen til skolene, prøver de nordiske landene å styrke profesjonsrelevansen på andre måter. Dette skjer for eksempel ved å styrke forskning i utdanningen, ved å ha nasjonale rammeplaner og ved å etablere partnerskapsmodeller mellom lærerutdanning og praksisskoler (Haugaløkken \& Ramberg, 2007; Lejonberg et al., 2018; Lillejord \& Børte, 2016; Smith, 2016).

I kunnskapsgrunnlaget om lærerrollen i Norge (Ekspertgruppa om lærerrollen, 2016) ble det konkludert med at partnerskap mellom høyere utdanning og skoler om lærerutdanning måtte styrkes, og videre at institusjonene må styrke arbeidet med en forskningsbasering av utdanningene. I den norske Nasjonal strategi for kvalitet og samarbeid i lcererutdanningene, «Lærerutdanning 2025,» signaliserer regjeringen at de vil utvikle nasjonale rammer for partnerskap med lærerutdanningsskoler og lærerutdanningsbarnehager (Kunnskapsdepartementet, 2017), og lignende tendenser ses i de øvrige nordiske landene. Målet er en styrket praksisopplæring og FoU-samarbeid gjennom lærerutdanningsskoler og lærerutdanningsbarnehager. Et annet viktig mål for disse partnerskapene er å utvikle 
langsiktig, bindende samarbeid som er av gjensidig verdi for skolen og universitetet. På lang sikt skal dette samarbeidet mellom skole og universitet gjøre det mulig for lærerstudenter å utvikle sin identitet som profesjonelle lærere. I partnerskapene prøves det blant annet ut nye former for praksis og nye samarbeidsformer og arenaer for samarbeid mellom skole og universitet. I dette temanummeret presenteres studier fra flere partnerskap i lærerutdanningen i Norge, Danmark og Finland. Disse studiene kan bidra til et kunnskapsgrunnlag for hvordan rammene for lærerutdanningsskoler kan utformes.

Bak ideen om partnerskap ligger erkjennelsen av at lærerstudenten må ha tilgang til ulike typer pedagogisk kunnskap som ledd i sin profesjonsutdanning. Den kunnskapen studentene tilegner seg gjennom erfaringer i praksis, skiller seg kvalitativt fra den akademiske kunnskapen de tilegner seg gjennom teoretiske studier ved universitet og høyskoler. Lærerne i skolen og lærerne ved lærerutdanningsinstitusjonen sitter altså inne med ulike typer profesjonskunnskap, begge viktige i lærerutdanningssammenheng. Flere tilnærminger brukes til å integrere teoretiske studier og undervisningspraksis i nordiske partnerskapsmodeller (Haugaløkken \& Ramberg, 2007; Lejonberg et al., 2018; Sandvik, 2020; Smith, 2016). Ikke bare skal partnerskapet omfatte praktisk opplæring for lærerstudenter; det skal også gjøre det mulig for dem å skaffe seg både praktisk og teoretisk kunnskap gjennom hele utdanningen.

En nøkkelrolle i lærerutdanningen er praksisveilederen i skolen. Flere av partnerskapene mellom skole og lærerutdanning som diskuteres i dette temanummeret, omhandler utdanning av kyndige praksisveiledere. En veileders evne til å reflektere over og analysere ikke bare veiledning, men også undervisning generelt, er avgjørende for å integrere veiledere i lærerutdanningen (Korthagen, 2004). Videre understreker Korthagen (2004) viktigheten av veilederes evne til å reflektere over nye læreres faglige utvikling for å være forberedt på utfordringer som de møter gjennom sine praksisorienterte erfaringer. Veiledernes evne til å anvende teori og deres forskningsbaserte holdning til undervisning og veiledning er sentrale elementer for å utvikle profesjonelle veiledere som føler seg integrert i lærerutdanningen (Aspfors \& Fransson, 2015; Sandvik et al., 2019). Følgestudier av en skolebasert videreutdanning av veiledere i universitetsskoler viser at veilederne i skolen opplevde utdanningen som et viktig ledd i å bli mer profesjonelle som veiledere for lærerstudentene (Emstad \& Sandvik, 2020).

Det å integrere FoU-samarbeid i et partnerskap mellom skole og universitet krever endring og utvikling av eksisterende praksis og etablering av nye praksiser. De nye partnerskapsmodellene som utvikles i Norden, bør derfor betraktes som omfattende organisasjonsutviklingsprosjekter som vil påvirke både universitetet og skolene og sette nye krav til både lærere og ledelse i begge organisasjonene. Det er derfor behov for å etablere en felles enighet om roller, rettigheter og ansvar innenfor disse partnerskapene for å utvikle solide relasjoner mellom skolebaserte lærere og universitetsbaserte lærerutdannere. Et bærekraftig partnerskap er basert på likeverd (Smith, 2016), og det handler om samarbeid som må ta hensyn til både 
organisatoriske og relasjonelle nivåer på nye måter. For å få ny kunnskap om hvordan de nye modellene for partnerskap fungerer i Norden, trenger vi studier som diskuterer dette.

\section{Presentasjon av artikler knyttet til partnerskap i lærerutdanningen}

Universitetsskoler har de siste årene blitt etablert i de skandinaviske landene som et sentralt strategisk grep for å styrke kvaliteten til praksisopplæringen i lærerutdanningen og fremme FoU-kompetansen i skolene. Selv om Finland har hatt ulike varianter av universitetsskoler i årtier, er dette et relativt nytt fenomen i de skandinaviske landene. Carlsen og von Oettingen utfordrer i sin artikkel forståelsen av hva forskning i en lærerutdanningskontekst skal være. De bygger på erfaringer fra universitetsskoler i Danmark og presenterer et transformatorisk forskningsbegrep for lærerutdanningen, som skiller mellom teori, empiri og praksis. Hatlevik, Engelien og Jorde bidrar med ny kunnskap om hvordan utvidede partnerskap kan fremme kvalitetsutvikling av mer enn bare studentenes praksisopplæring. De presenterer ulike eksempler på samarbeid basert på ti års erfaring med universitetsskolesamarbeid med utvalgte ungdoms- og videregående skoler knyttet til Universitetet i Oslo. I artikkelen presenterer de indikatorer på velfungerende partnerskapssamarbeid mellom lærerutdanningsinstitusjon og praksisfelt som de har utviklet på grunnlag av tidligere forskning, som de sier kan være til støtte også i planlegging og evaluering av andre partnerskap. Emstad og Sandvik presenterer en studie som har undersøkt hvordan et partnerskap mellom universitet og skole i tett samarbeid har lagt til rette for skolebasert videreutdanning i veiledning og FoU. All undervisning ble lagt til egen arbeidsplass, og det ble lagt vekt på tett samarbeid i både utviklingen av læreplanene og gjennomføringen av videreutdanningen. Artikkelen argumenterer for hvordan et tett samarbeid i alt fra utvikling av studieplan til gjennomføring av studiet kan bidra til intern forpliktelse og engasjement for egen utvikling som veileder. Den neste artikkelen er en komparativ studie om praksisundervisningen i Norge og Finland. På grunnlag av historiske analyser og tematiske narrativer gir Østern, Svedlin og Engvik oss en forståelse for hvordan praksisundervisningen i lærerutdanningen i Finland og Norge har utviklet seg siden 1800-tallet. Forfatterne argumenterer for at Finland har styrket posisjonen som et senter for pedagogisk innovasjon, forskning og veiledning, mens Norge kommer etter, men at begge landende driver profesjonalisering av veiledningen gjennom både eksterne og interne krefter. Den siste artikkelen i denne delen av temanummeret, av Hontvedt, Oddvik og Næss, rapporterer fra et pågående utviklingsarbeid der et konsept kalt videolekser ble introdusert for å få innsikt i studenters lese- og læringsprosess på et samlingsbasert masterstudium for lærere. Forfatterne konkluderer med at bruken av video har potensial til å skape felles omdreiningspunkt i utdanningen, og at den har et potensial som gjensidig ansvarliggjørende for studenter og lærerutdannere. 


\section{Relevans i lærerutdanningen}

I temanummerets andre del fokuseres det på utdanningenes relevans. For mange av partnerskapsmodellene handler det om samarbeidsprosesser og hvordan de er organisert og systematisk ledet i skjæringspunktet mellom universitet, skoler og fylke/kommune (Callahan \& Martin, 2007). Dermed er samarbeidsperspektiv og hvordan forhandlingene foregår i det «tredje rom» (Boland \& Tenkasi, 1995) avgjørende for suksessen i de nye partnerskapsmodellene. Som kunnskapsorganisasjoner er dessuten skolene og lærerutdanningene avhengige av kompetansen og handlingene til de ansatte. Modeller, organisasjonsformer og lederskap i universitetsskolene er således avhengige av de ulike tradisjonene og praksisene i de ulike organisasjonene med hensyn til: 1) Hva som er den dominerende konseptualisering av kunnskap og pedagogikk i organisasjonene, og 2) Hva som framstår som de organisatoriske og ledende strategiene, med særlig fokus på de som arbeider der og hvordan samarbeidet framstår (Drucker, 1994).

Et sentralt tiltak for å styrke den disiplinfaglige komponenten og profesjonsrelevansen i lærerutdanningen i Norge er utvikling av femårige lærerutdanninger med mastergrad. Siden 2003 har Norge hatt femårige lektorutdanninger med mastergrad, og høsten 2017 startet de første studentkullene opp på femårige grunnskolelærerutdanninger. Formålene med de femårige lærerutdanningene er å styrke både undervisningsfagene og praksisopplæringen. Kjernen i mastergraden ligger i muligheten til faglig fordyping, forskningsforankring og metoder for å kunne løse komplekse oppgaver i et samfunn i endring. En femårig masterutdanning vil gi studentene bedre vilkår for å få den faglige, pedagogiske og didaktiske trygghet de trenger i framtidens skole.

«Lærerutdanning 2025» beskriver FoU som nøkkelen til kvalitetsutvikling i lærerutdanningene, barnehagen og skolen, og i de nasjonale kravene er det fastsatt at lærerutdanningen i Norge skal være integrert, anvendt, praktisk orientert og forskningsbasert. Gjennom et masterstudium skal lærerstudenters engasjement både med og i forskning forsterkes, der studentene forventes å trekke på etablert forskning for å utvikle sin tenkning og praksis, og lærer å forske på egen praksis gjennom ulike arbeidskrav gjennom utdanningen, som for eksempel FoUoppgaver. I de ulike utdanningsinstitusjonene realiseres profesjonsrelevansen i masteroppgaven på forskjellig vis: Ved noen institusjoner er studentenes masteroppgaver knyttet til relevante praksisutfordringer, ved andre er masteroppgaven knyttet tettere opp mot disiplinfaglige problemstillinger. I dette temanummeret diskuteres denne relevansproblematikken.

Et mulig dilemma knyttet til en femårig lærerutdanning med sterk forskningsforankring er det såkalte teori-praksisdilemmaet. Mens skolens læreplaner understreker behovet for en mer relevant og praktisk opplæring av elevene, viser studier at lærerstudenter får mest erfaring med stillesittende og kognitive læringsformer i lærerutdanningen og at de i liten grad får oppleve og prøve ut elevaktive læringsformer (Skagen, 2010). Samtidig viser det seg at det er en klar, positiv 
sammenheng mellom studentenes erfaringer med elevaktive læringsformer og deres vurdering av egen kompetanse til å bruke dem. Likevel viser studier at nyutdannede lærere har en tendens til å vende tilbake til mer tradisjonelle læringsformer etter kort tid som utøvende lærere (Engvik, 2016). Det viser seg at nyutdannede lærere i sitt arbeid vektlegger erfaringer fra praksis mer enn det de har lært av teori i lærerutdanningen. Det betyr at dersom elevaktive undervisningsformer skal få gjennomslag i praksis, må studentene ikke bare få erfare, men også planlegge og gjennomføre elevaktive arbeidsformer med elever i skolen (Skagen, 2010).

\section{Presentasjon av artikler knyttet til relevans i lærerutdanningen}

Universitet i Tromsø Norges arktiske universitet var først ute med et femårig masterprogram i grunnskolelærerutdanning, og to av artiklene presenterer studier tilknyttet det longitudinelle forskningsprosjektet «Relevant masterutdanning for grunnskolelærere» (RELEMAST). Først ute er Antonsen, Maxwell, Bjørndal og Jakhelln, som presenterer en studie som har undersøkt hvordan nyutdannede grunnskolelærere erfarer at den formelle lærerkompetansen de har med seg fra utdanningen, samsvarer med deres behov for kunnskap om spesialpedagogikk og tilpasset opplæring i yrkesstarten. Resultatene viser at de nyutdannede lærerne opplever at det er utfordrende å tilpasse opplæringen for en sammensatt elevgruppe, og at de mangler spesialpedagogisk kompetanse på flere områder for å utføre sine arbeidsoppgaver relatert til funksjonene som faglærer, kontaktlærer og spesialundervisning. De etterspør også kunnskap om å møte støtteapparatet, som PPT, BUP og barnevern, spesielt for elever med behov for særskilt tilrettelegging. Den andre artikkelen, skrevet av Bjørndal, Antonsen og Jakhelln, presenterer en studie som har undersøkt hvordan nyutdannede lærere med master i grunnskolelærerutdanning anvender sin FoU-kompetanse i skolen i de to første yrkesårene. FoU-kompetansen de nyutdannede har med seg fra lærerutdanningen gir et kunnskapsgrunnlag for utvikling og forbedring av egen praksis, grunnlag for refleksjon over sin praksis og grunnlag for forbedring av undervisningspraksis og klasseledelse. Likevel opplever de nyutdannede lærerne at det er utfordrende å benytte FoU-kompetansen i skolen i sine første yrkesår. Forfatterne peker på at det både i skolens organisasjon og hos nyutdannede fortsatt er behov for mer kunnskap og forståelse for FoU. Videre peker de på at lærerutdanningen har et forbedringspotensial i sitt arbeid med å utvide studentenes forståelse av FoUkompetanse, men at det også er faktorer i skolen som påvirker mulighetene til FoU-arbeid negativt. Det handler om tid, utfordrende elever og klasseledelse, kontaktlæreransvar og pålegging av undervisning i fag uten kompetanse. Noen av disse faktorene er de samme som Emstad, Strømme, Knutsen og Lysne viser til i sin aksjonsforskningsstudie om hvordan forsterket oppmerksomhet på uteskole i lærerutdanningen kan ha betydning for bruk av uteskole i første yrkesår. Funnene indikerer at autentiske erfaringer med uteskole i lærerutdanningen kan skape positive holdninger og tro på egne kunnskaper og ferdigheter til å gjennomføre 
uteskole. Som studien til Bjørndal m.fl. viser, er det ikke nok å gjøre endringer i lærerutdanningen, det er også viktig med støtte og rammefaktorer som legger til rette for at de nyutdannede lærerne skal få muligheter til utprøving, enten det gjelder uteskole eller FoU. Den neste artikkelen rapporterer fra en studie som er basert på eksamenstekster skrevet av deltakere i en videreutdanning for praksislærere i yrkesfag i en videregående skole. I artikkelen løfter Hansen fram et nyansert bilde av mesterlære i bruk når hun belyser studentenes refleksjoner over muligheter og utfordringer i praksisopplæringen. Hun viser til at praksislærerne opplever utfordringer med den «usynlige» mesteren, de ønsker i større grad å være modell-lærere, vise sin kunnskap til praksisstudenten, både kroppslig og gjennom annen form for kommunikasjon. Hansen viser til at praksislærerne har et ønske om at andre ressurser kan bringe inn nye perspektiver, det være seg andre praksislærere, faglærere, medstudenter eller andre i skoleorganisasjonen. Holmbukt og Son tar utgangpunkt i utfordringen med at studenter som studerer engelsk som en del av sin grunnskolelærerutdanning, har problemer med å omforme akademisk kunnskap til praktisk anvendelse i klasserommet. I studien diskuterer og evaluerer de en undervisningsstrategi som har til hensikt å imøtekomme denne utfordringen gjennom å implementere en epistemologi i lærerutdanningen som tar i bruk et tredje rom. De beskriver det tredje rom som en arena som integrerer akademisk kunnskap og praksis i klasserommet, og som sikter mot å utvikle studentenes fag- og undervisningskompetanse. 


\section{Om redaktørene}

Lise Vikan Sandvik er professor i skoleutvikling og veiledning ved NTNU. Hennes forskningsinteresser omfatter blant annet vurdering, skoleutvikling, partnerskap i lærerutdanning og veiledning av lærerstudenter. Hun leder et forskningsprosjekt om skolebasert profesjonsutvikling som tar sikte på å utvikle vurderingskompetanse blant ledere og lærere i 21 videregående skoler. Institusjonstilknytning: Institutt for lærerutdanning, NTNU, 7491 Trondheim. E-post: lise.sandvik@ntnu.no

Anne Berit Emstad er innovasjonsleder ved NTNU. Hun har flere års erfaring fra skolelederutdanningen ved Institutt for lærerutdanning ved NTNU. Hennes forskningsinteresser er knyttet til ledelse i skole og kulturskole, skoleutvikling, lærerutdanning og nyutdannede lærere.

Institusjonstilknytning: Institutt for lærerutdanning, NTNU, 7491 Trondheim.

E-post: anne.emstad@ntnu.no

Simon Skov Fougt er lektor i literacy ved Dansk Center for Skoleforskning ved Aarhus Universitet. Hans forskningsinteresser omfatter blant annet lesing, multimodalitet, scenariedidaktikk, læremidler og lærerprofesjonalitet.

Institusjonstilknytning: Danmarks Institut for Pædagogik og Uddannelse, Aarhus Universitet, København.

E-post: sifo@edu.au.dk

\section{Referanser}

Alfdal, H. W. (2012). Constructing knowledge for the teacher profession - a comparative analysis of policy making, curricula content, and novice teachers' knowledge relations in the case of Finland and Norway. Doktoravhandling, Oslo.

Aspfors, J. \& Fransson, G. (2015). Research on mentor education for mentors of newly qualified teachers: A qualitative meta-synthesis. Teaching and Teacher Education, 48, 7586. https://doi.org/10.1016/j.tate.2015.02.004

Boland, R. J. \& Tenkasi, R. V. (1995). Perspective Making and Perspective Taking in Communities of Knowing. Organization Science, 6(4), 350-372. https://doi.org/10.1287/orsc.6.4.350

Callahan, J. L. \& Martin, D. (2007). The spectrum of school-university partnerships: A typology of organizational learning systems. Teaching and Teacher Education, 23(2), 136145. https://doi.org/10.1016/j.tate.2006.04.038

Drucker, P. F. (1994). Post-Capitalist Society. Routledge.

Ekspertgruppa om lærerrollen (2016). Om lærerrollen. Bergen: Fagbokforlaget. 
Emstad, A. B. \& Sandvik, L. V. (2020). School-University collaboration for facilitating inservice training as a part of school-based professional development. Acta Didactica Norden, 14(2), Art. 3. http://dx.doi.org/10.5617/adno.6995

Engvik, G. (2016). Skolens yrkeskultur som grunnlag for veiledning og læring i lærernes første yrkesår. I A.-L. Østern \& G. Engvik (red.), Veiledningspraksiser i bevegelse: Skole, utdanning og kulturliv (s. 213-231). Bergen: Fagbokforlaget.

Hargreaves, A. \& Fullan, M. G. (2012). Professional capital: Transforming teaching in every school. New York: Teachers College Press.

Haugaløkken, O. K. \& Ramberg, P. (2007). Autonomy or control: Discussion of a central dilemma in developing a realistic teacher education in Norway. Journal of Education for Teaching, 33(1), 55-69. https://doi.org/10.1080/02607470601098310

Korthagen, F. A. J. (2004). In search of the essence of a good teacher: Towards a more holistic approach in teacher education. Teaching and Teacher Education, 20(1), 77-97. https://doi.org/10.1016/j.tate.2003.10.002

Korthagen, F. A. J. (2010). Situated learning theory and the pedagogy of teacher education: Towards an integrative view of teacher behavior and teacher learning. Teaching and Teacher Education, 26(1), 98-106. https://doi.org/10.1016/j.tate.2009.05.001

Kunnskapsdepartementet (2017). Læererutdanning 2025. Nasjonal strategi for kvalitet og samarbeid i lererutdanningene. Oslo: Kunnskapsdepartementet.

Lejonberg, E., Elstad, E. \& Christophersen, K. A. (2018). Teaching evaluation: Antecedents of teachers' perceived usefulness of follow-up sessions and perceived stress related to the evaluation process. Teachers and Teaching, 24(3), 281-296. https://doi.org/10.1080/13540602.2017.1399873

Lid, S. E. (2013). PPUs relevans for undervisning i skolen. En kartlegging av studenters og nyutdannede læereres oppfatninger. NOKUTs utredninger og analyser.

Lillejord, S. \& Børte, K. (2016). Partnership in teacher education - a research mapping. European Journal of Teacher Education, 39(5), 550-563. https://doi.org/10.1080/02619768.2016.1252911

Sandvik, L. V. (2020). NTNUs forskningsbaserte universitetsskolemodell. I E. Elstad (red.), Lœrerutdanning i nordiske land (s. 256-276). Oslo: Universitetsforlaget.

Sandvik, L. V., Solhaug, T., Lejonberg, E., Elstad, E. \& Christophersen, K.-A. (2019). School mentors' perceived integration into teacher education programmes. Professional Development in Education, 1-16. https://doi.org/10.1080/19415257.2019.1623286

Skagen, K. (2010). Teori og praksisopplæring i lærerkvalifisering. I P. Haug (red.), Kvalifisering til leraryrket (s. 118-139). Oslo: Abstrakt forlag.

Smith, K. (2016). Partnerships in teacher education - Going beyond the rhetoric, with reference to the Norwegian context. CEPS Journal, 6(3), 17-36.

Timperley, H., Wilson, A., Barrar, H. \& Fung, I. (2007). Teacher professional learning and development. Ministry of Education, University of Auckland. 